\title{
Investigation of the effects of different central steel brace type on nodal point connection detail and building behaviour
}

\author{
Farklı merkezi çelik çapraz tipinin düğüm noktası birleşim detayına ve bina davranışına \\ etkilerinin incelenmesi
}

Şenol GÜRSOY*1,a, Büşra CENGIZZ,b

${ }^{1}$ Karabük University, Faculty of Engineering, Department of Civil Engineering, 78050, Karabük

${ }^{2}$ Karabük University, Graduate Education Institute, Department of Civil Engineering, 78050, Karabük

• Geliş tarihi / Received: 17.07.2021

• Düzeltilerek geliş tarihi / Received in revised form: 21.10 .2021

• Kabul tarihi / Accepted: 27.10.2021

\begin{abstract}
High strength and ductility properties of steel structures have been the reason for the preference against earthquake effects. However, it has observed that significant damages occurred in particularly the nodal point connection of the steel structures in the investigations made after the earthquakes. Therefore, it is very important to know the effect of different central steel brace and nodal point connection type on steel structure behavior. The main purpose of this study is to comparatively examine the effects on the behavior of steel structures of the different central braced types and nodal point connection detail. The findings obtained from structural analyses reveal that different central steel brace members contribute positively to the behavior of steel structures. This result shows that central steel braced that increase the performance of steel structures are very important. In Turkey, particularly in terms of the safety and performance of the steel structures to be constructed in earthquake zones is proposed to prefer steel structural systems with bidirectional central steel braces.
\end{abstract}

Keywords: Center steel braces, Design of steel structures, Sta-Steel, Steel structural systems

$\ddot{\boldsymbol{O}} \boldsymbol{z}$

Çelik yapıların yüksek dayanım ve süneklik özelikleri deprem etkilerine karşı tercih edilme nedeni olmaktadır. Ancak depremler sonrasında yapılan incelemelerde çelik yapıların özellikle birleşim bölgelerinde önemli hasarların meydana geldiği gözlemlenmiştir. Bu nedenle farklı merkezi çelik çaprazların ve düğ̈̈m noktası birleşiminin türünün çelik yapı davranışına etkisini bilmek çok önemlidir. Bu çalışmanın temel amacı farklı merkezi çapraz tiplerinin ve düğüm noktası birleşim detayının çelik yapıların davranışlarına etkisini karşılaştırmalı olarak incelemektir. Yapısal çözümlemelerden elde edilen bulgular, farklı merkezi çelik çapraz elemanların çelik yapıların davranışlarına olumlu katkı sağladı̆̆ını ortaya koymaktadır. Bu sonuç çelik yapıların performansını artıran merkezi çelik çaprazların oldukça önemli olduğunu göstermektedir. Türkiye'de özellikle deprem bölgelerinde inşa edilecek çelik yapıların emniyeti ve performansı bakımından iki yönlü merkezi çelik çaprazlara sahip çelik taşıyıcı sistemlerinin tercih edilmesi önerilmektedir.

Anahtar kelimeler: Merkezi çelik çaprazlar, Çelik yapıların tasarımı, Sta-Steel, Çelik taşıyıcı sistemler

\footnotetext{
*a Şenol GÜRSOY; sgursoy@karabuk.edu.tr, Tel: (0370) 41870 60, orcid.org/0000-0001-8133-0906

${ }^{\mathrm{b}}$ orcid.org/0000-0003-0899-8007
} 


\section{Introduction \\ 1. Giriş}

It is seen that the most common use of steel structures in Turkey is in industrial buildings. On the other hand, after the earthquakes that took place in recent years, the buildings have increased in the interest in the use of steel materials, too. This situation further increases the importance of constructing steel structures in accordance with the design and technique. Because the main feature expected from the structures built and/or to will be built in Turkey where almost all lands are at earthquakes hazard is that they are resistant to earthquakes. However, to minimize the structural damages resulting from earthquakes that will occur, it is necessary to correctly understand the earthquake behaviours of the structures in question and make appropriate designs. For this purpose, some researchers have investigated the behaviour of steel structural systems with different stiffness elements added to reduce the effects of especially earthquakes (Gönen, 1997; Tama, 2003; Ay et al., 2010; Kural \& Zeybek, 2011; Özçelik, 2016; Yelgin \& Bulut, 2016; Çavdar, 2017; Çavdar, 2019).

The selection and sizing of steel structural systems is related to the number of stories. Because as the number of stories increases, horizontal loads such as wind and earthquake acting on the structure to increase and these increasing loads are more effective than vertical loads. In cases where this horizontal load acting on the steel structure is more effective according to the vertical load, the importance of braced frame types more increases to meet the said horizontal loads. In the design of steel structures, frames with central steel braces can be used, as well as frames with external central steel braces, too. However, the easiest to design and most preferred especially in the construction of industrial structures are steel frames with central braces. But the ductility of central braced steel frames is lower than other types of frames (external central steel braced frames and momenttransferring steel frames). In addition, brittle fractures formed in the brace nodal point connections of the central braced frames are as the biggest problem. For this reason, the design of brace nodal point connections should be calculated according to the maximum force that can be transferred from the braces.

This article aims to determine the effects of the central steel brace types used in the design of steel structures in Turkey on the performance of the structure in question. For this purpose, by taking the moment-transmitting frame as the reference model (model 1), the X, V, $\Lambda$ and / diagonal braced structural models were created according to the conditions of the Turkish Building Earthquake Code (TBEC, 2019) and the Regulation on the Design, Calculation and Construction Principles of Steel Structures (ÇYTHYDE, 2018). Structural analyses of the central braced steel structure models selected as an example was made with the Sta-Steel program (Sta-Steel, 2019). Thus, some conclusions were presented by comparing the obtained findings.

\section{Frames with central steel brace by Turkey building earthquake regulations}

2. Türkiye bina deprem yönetmeliğine göre merkezi çelik çaprazlı çerçeveler

Steel braced frames are systems that can form a central or external center and can carry horizontal loads. Central Steel Braced Frames (CSBF) systems are formed by connecting the axes of columns, beams and cross members forming the nodal point by overlapping. In addition, CSBF systems can be designed in two ways: ductility level limited (DLL) and ductility level high (DLH). External Center Braced Steel Frames (ECBSF) systems are formed by connecting the cross members to the nodal points as an external center. However, ECBSF systems can only be designed as DLH.

In CSBF systems with DLH, even if some of the brace members exposed to pressure effects are twisted, dimensioning in such a way that significant strength loss does not occur in the structural system should be done. On the other hand, CSBF systems are damping the earthquake energy to a significant extent when the braces subjected to pressure effects reach the yield strength by buckling and the braces subjected to tensile effects reach the yielding state due to tensile effects. Therefore, CSBF systems show very good plastic behaviour. In addition, since the brace members in these systems meet all the horizontal loads, all plastic deformations are expected to occur in these elements, while columns, beams, and nodal points are required to remain in the elastic region (Türk, 2016). However, since they are designed to withstand large dynamic effects, their ductility is lower than that of moment-transmitting frames. In the Turkish Building Earthquake Code (TBEC), which came into force in 2019, CSBF systems are given in Figure 1. 


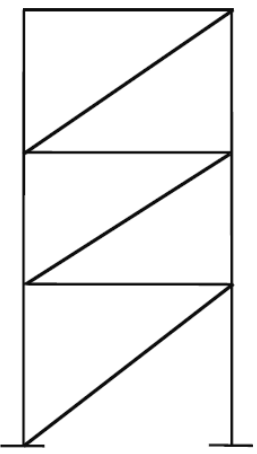

Diagonal braced

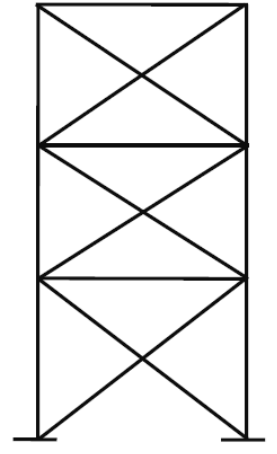

$\mathrm{X}$ braced

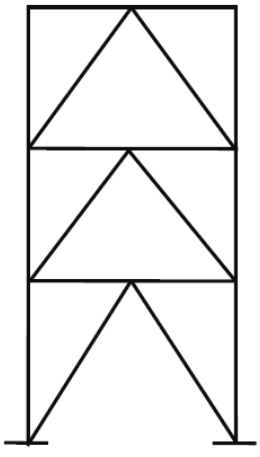

$\Lambda$ braced



$\mathrm{V}$ braced

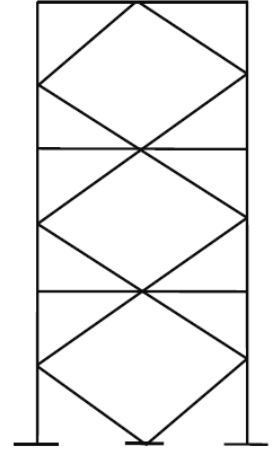

K braced

Figure 1. Types of CSBF according to Turkish Building Earthquake Code (TBEC, 2019)

Şekil 1. Türkiye bina deprem yönetmeliğine göre merkezi çelik çaprazlı çerçeve (CSBF) tipleri (TBEC, 2019)

\section{Study method}

\section{3. Çalışma metodu}

The numerical applications of this study, it consists of 8 steel building models, symmetrical in plan and with three spans having each span $6 \mathrm{~m}$ in both directions, and 5 stories with each storey $3 \mathrm{~m}$ high. The structural systems of the formed building models consist of 8 different models as momenttransmitting frame and $\operatorname{CSBF}(/, \mathrm{X}, \mathrm{V}$ and $\Lambda$ ). In addition, it is accepted that the selected building models are symmetrical in both directions to avoid additional section effects due to structural torsion (Cengiz, 2020).
All columns HE 300B, main beams IPE 270, intermediate beams in the y-direction IPE 240 and $\mathrm{x}$-direction IPE 220 of each steel structure model (moment transmitting frame, $\mathrm{X}$ braced frame, $\mathrm{V}$ braced frame, $\Lambda$ braced frame and / diagonal braced frames) were created with profiles. In structural analyses, nodal point connections have modelled as rigid before forming bolted connections. In addition, the structural analyses of the CSBF building models were carried out according to the ZB local soil class (Cengiz, 2020). Other features of the steel buildings models selected as examples are given Table 1.

Table 1. Other structural features of the steel buildings models

Tablo 1. Çelik bina modellerinin diğer yapısal özellikleri

\begin{tabular}{|c|c|c|c|c|c|c|c|}
\hline \multirow{2}{*}{$\begin{array}{l}\text { Models } \\
\text { model } 1\end{array}$} & \multirow{2}{*}{$\begin{array}{c}\text { Frame type } \\
\begin{array}{c}\text { Moment transmitting } \\
\text { frame }\end{array}\end{array}$} & \multirow{2}{*}{$\begin{array}{c}\begin{array}{c}\text { All } \\
\text { columns }\end{array} \\
\text { HE 300B }\end{array}$} & \multirow{2}{*}{$\begin{array}{c}\begin{array}{c}\text { Main } \\
\text { beams }\end{array} \\
\text { IPE } 270\end{array}$} & \multicolumn{2}{|c|}{$\begin{array}{c}\text { Intermediate beams } \\
\text { x-direction } y \text {-direction }\end{array}$} & \multirow{2}{*}{$\begin{array}{c}\text { Brace profiles using } \\
\text { in the outer axles } \\
-\end{array}$} & \multirow{2}{*}{$\begin{array}{l}\text { Explanation } \\
\text { see Figure 2a }\end{array}$} \\
\hline & & & & IPE 220 & IPE 240 & & \\
\hline model 2 & $\begin{array}{l}\text { Central X steel } \\
\text { braced frame }\end{array}$ & HE 300B & IPE 270 & IPE 220 & IPE 240 & R140x10 box & see Figure $2 b$ \\
\hline model 3 & $\begin{array}{l}\text { Central V steel } \\
\text { braced frame }\end{array}$ & HE 300B & IPE & IPE & 0 & $\mathrm{R} 140 \times 10$ & $2 \mathrm{c}$ \\
\hline model 4 & $\begin{array}{l}\text { Central } \Lambda \text { steel } \\
\text { braced frame }\end{array}$ & HE 300B & IPE 270 & IPE 220 & IPE 240 & R140x10 box & see Figure 2d \\
\hline model 5 & $\begin{array}{l}\text { Central / steel braced } \\
\text { frame }(\Lambda \text { formed on } \\
\text { the corner columns })\end{array}$ & HE 300B & IPE 270 & IPE 220 & IPE 240 & R140x10 box & see Figure 2e \\
\hline model 6 & $\begin{array}{l}\text { Central / steel braced } \\
\text { frame (V formed on } \\
\text { the corner columns) }\end{array}$ & HE 300B & IPE & 20 & IPE & R140x10 box & see Figure $2 \mathrm{f}$ \\
\hline model 7 & $\begin{array}{l}\text { Central / steel braced } \\
\text { frame (// formed on } \\
\text { the corner columns) }\end{array}$ & HE 300B & IPE 270 & IPE 220 & IPE 240 & R140x10 box & see Figure $2 g$ \\
\hline model 8 & $\begin{array}{l}\text { Central / steel braced } \\
\text { frame ( }(\backslash \text { formed on } \\
\text { the corner columns) }\end{array}$ & HE 300B & IPE 270 & IPE 220 & IPE 240 & R140x10 box & see Figure $2 \mathrm{~h}$ \\
\hline
\end{tabular}



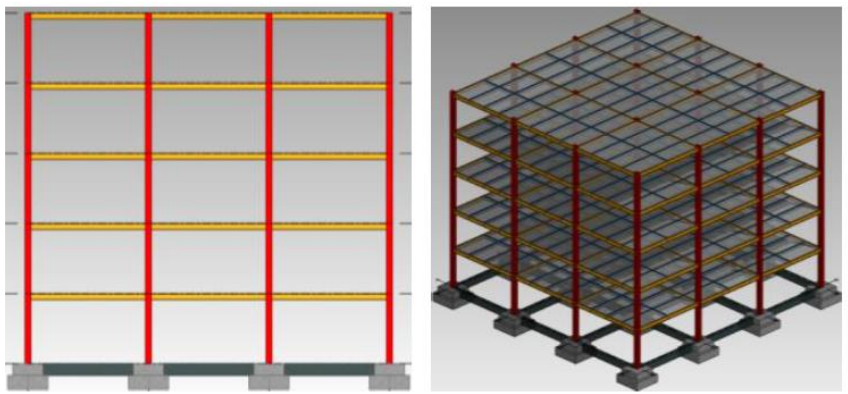

a) model 1
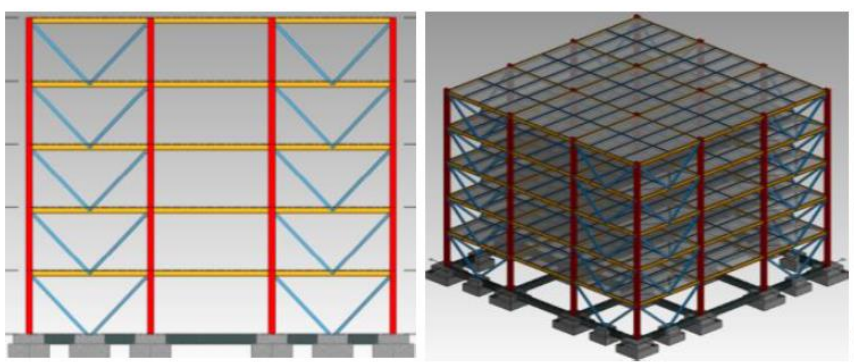

c) model 3
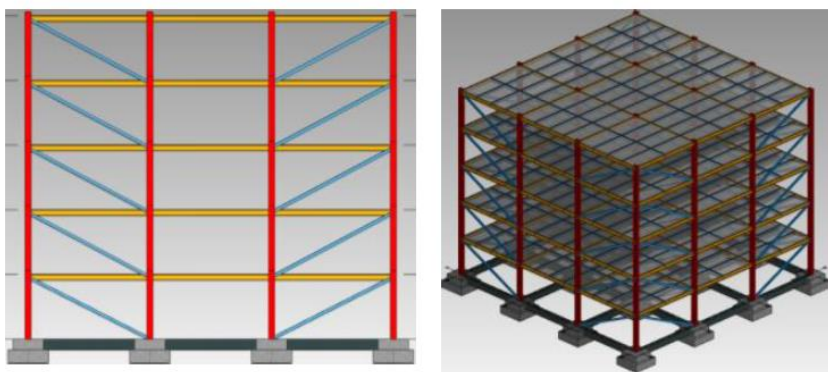

e) $\operatorname{model} 5$
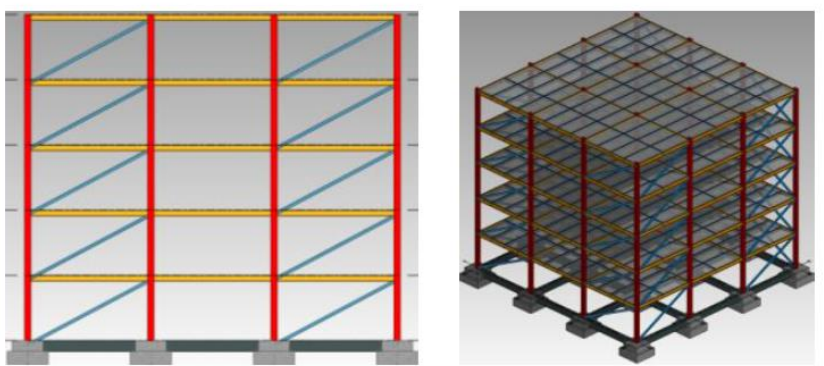

g) model 7

Figure 2. External axle section and 3D view of models Şekil 2. Modellerin dış aks kesiti ve 3 boyutlu görünümü

The foundation view and dimensions of the steel building models considered in this study are shown in Figure 3. In addition, the semi-rigid nodal point details of the central steel braced frames are formed bolted and welded as shown in Figure 4. Plate

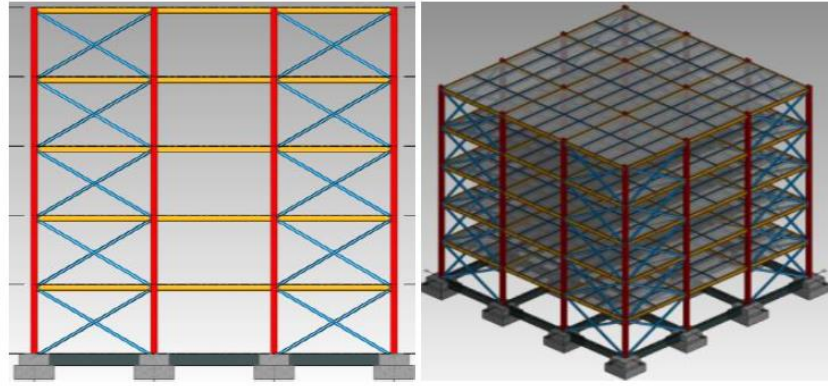

b) model 2



d) model 4

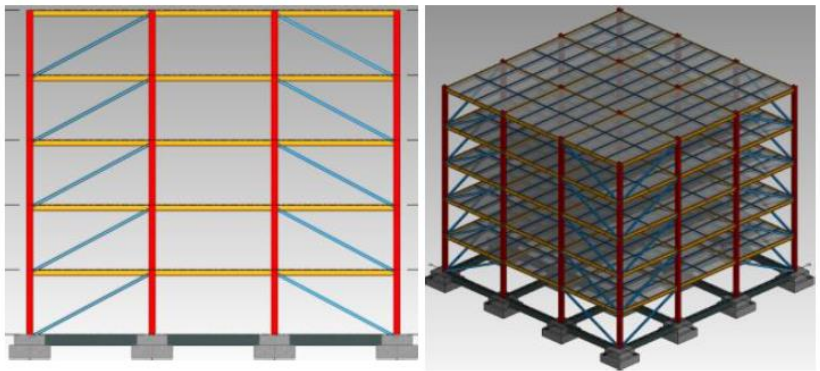

f) $\operatorname{model} 6$

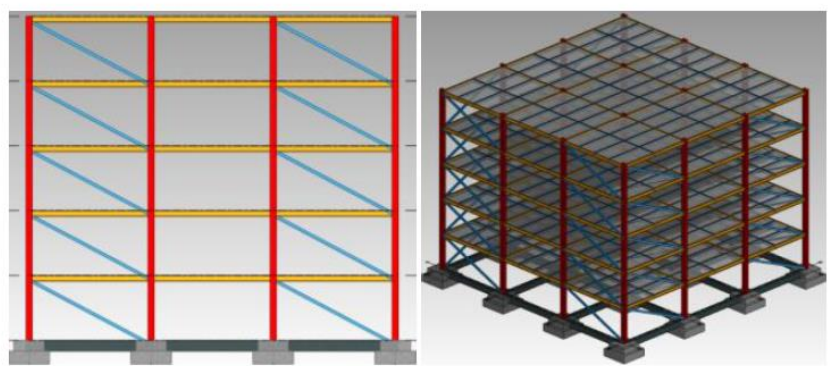

h) model 8

thicknesses seen in this figure are $20 \mathrm{~mm}$ and weld thicknesses are considered as $14 \mathrm{~mm}$.

Here, it would be useful to point out that the rigid column-beam nodal points are welded and the weld thickness in these nodal points is $14 \mathrm{~mm}$. 


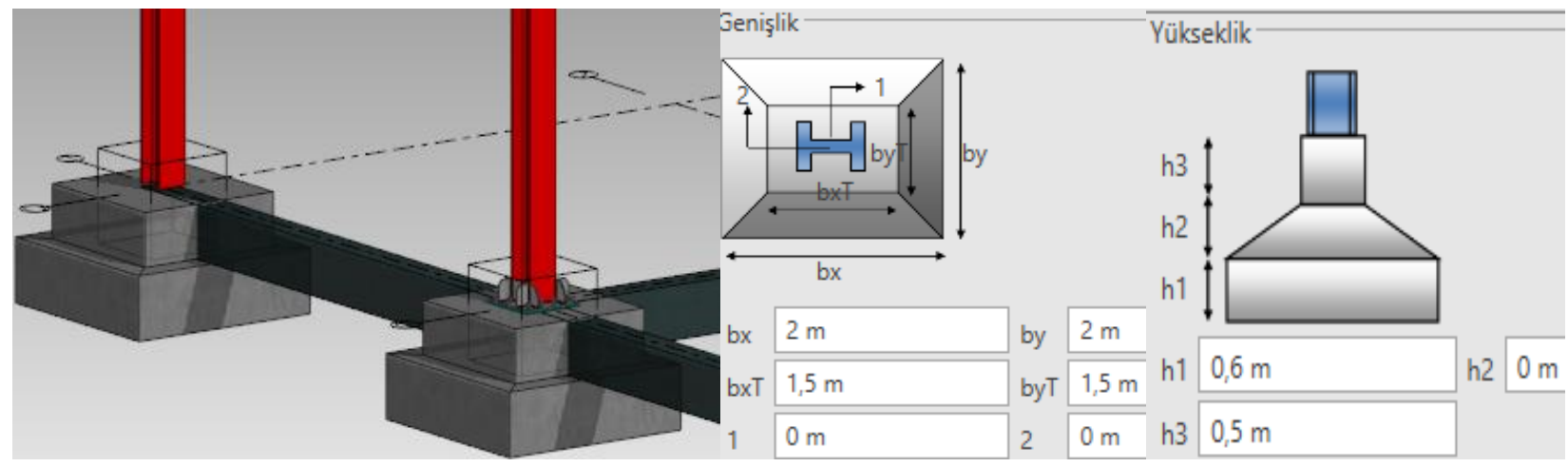

Figure 3. View and dimensions of the foundation system of steel building models

Şekil 3. Çelik bina modellerinin temel sisteminin görünümü ve boyutları

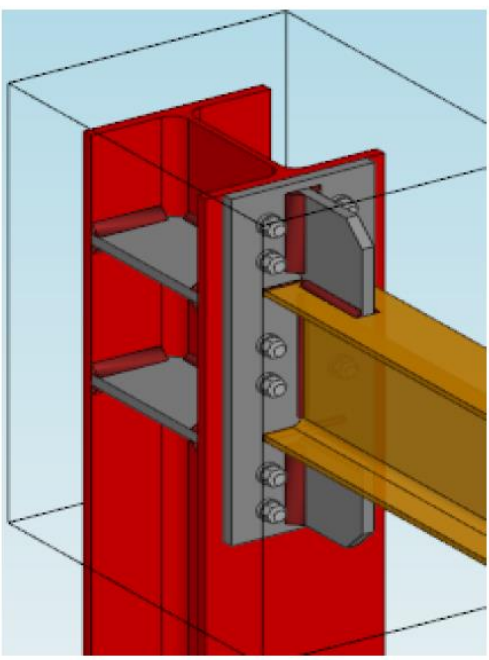

strong axis

a) Column-beam connection details

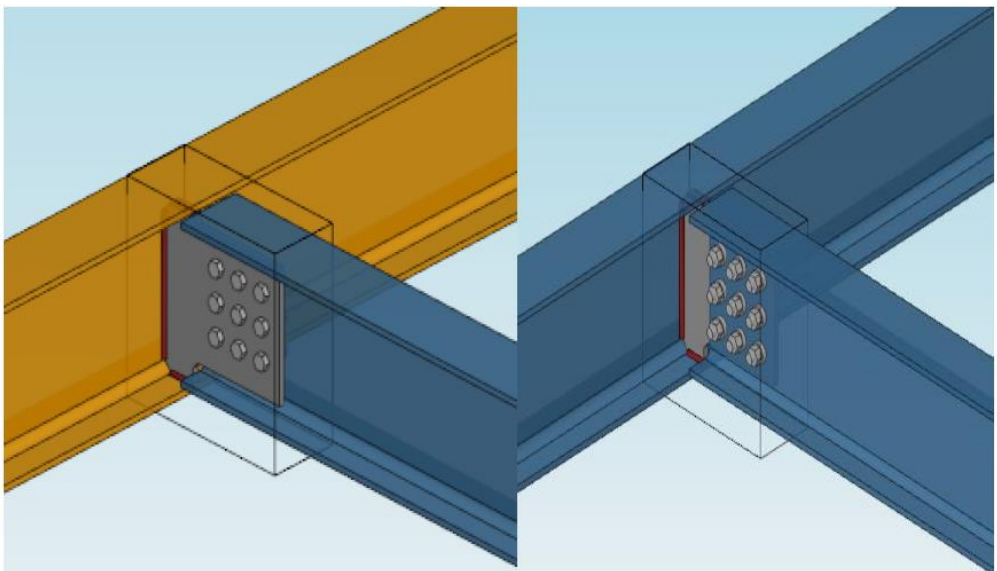

c) Main beam-intermediate beam connection detail

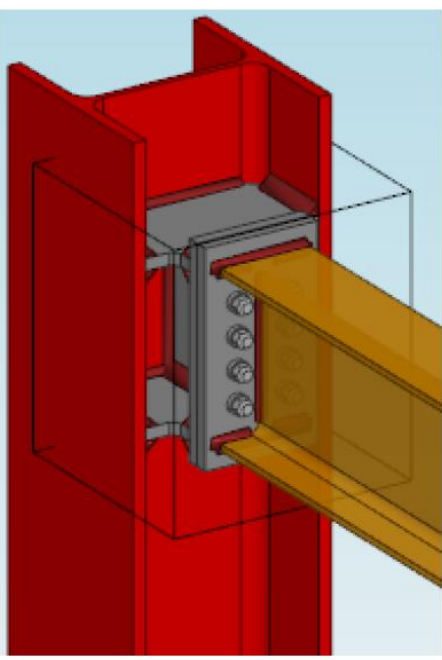

weak axis

d) Intermediate beam-intermediate beam connection detail

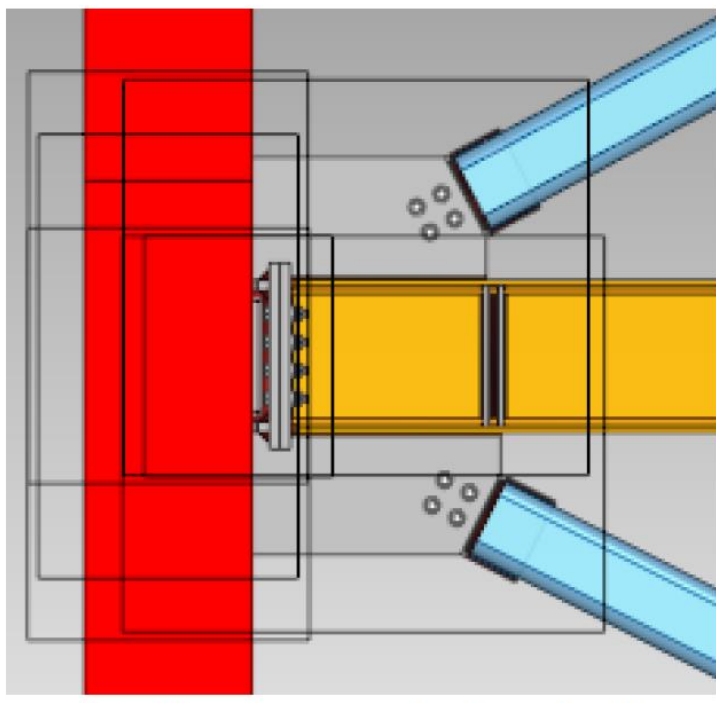

b) Column-beam-cross connection detail

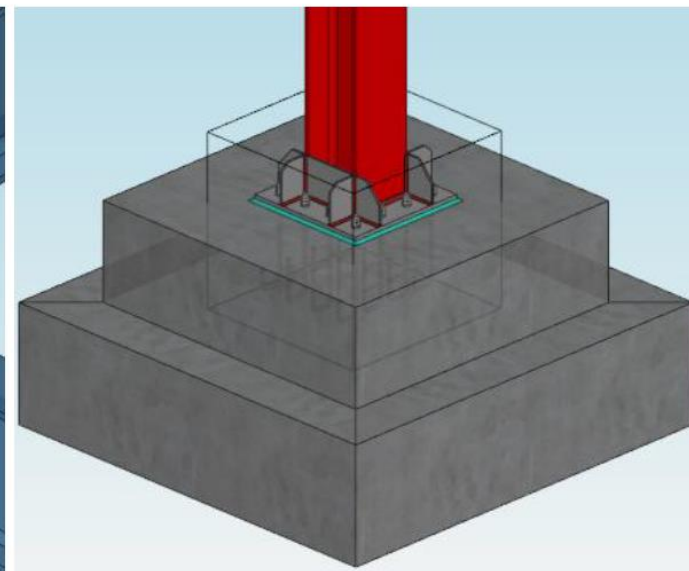

e) Column-foundation connection detail

Figure 4. Details of nodal point created as bolted and welded of the considered frames

Şekil 4. Dikkate alınan çerçevelerin bulonlu ve kaynaklı olarak oluşturulan düğüm noktası birleşim detayları

\subsection{Material properties of structural elements of steel building models}

3.1. Çelik bina modellerinin yapısal elemanlarının malzeme özellikleri

European profiles were used for dimensioning the structural elements. Accordingly, columns, beams and brace members have designed with $\mathrm{S} 275$ steel. Material properties related to S275 steel are given in Table 2. In addition, 8.8 bolt class has used in nodal point connections. The properties related to this bolt class are given in Table 3, too. Other 
design parameters of the building models are also given in Table 4. The snow load given in Table 4 was selected according to the province of Kütahya
(TS EN 1991-1-3, 2007). In addition, TS 498 regulation was used in the calculation of the wind load affecting the building models (TS-498, 1997).

Table 2. Characteristic yield stress, $F_{y}$ and tensile strength, $F_{u}$ of S275 material

Tablo 2. S275 malzemesinin karakteristik akma gerilmesi, $F_{y}$ ve çekme dayanımı, $F_{u}$

\begin{tabular}{|c|c|c|c|c|}
\hline \multirow{3}{*}{ Steel class } & \multicolumn{4}{|c|}{ Characteristic thickness, $\mathrm{t}(\mathrm{mm})$} \\
\hline & \multicolumn{2}{|c|}{$\mathrm{t} \leq 40 \mathrm{~mm}$} & \multicolumn{2}{|c|}{$40 \mathrm{~mm} \leq \mathrm{t} \leq 80 \mathrm{~mm}$} \\
\hline & $\mathrm{F}_{\mathrm{y}}\left(\mathrm{N} / \mathrm{mm}^{2}\right)$ & $\mathrm{F}_{\mathrm{u}}\left(\mathrm{N} / \mathrm{mm}^{2}\right)$ & $\mathrm{F}_{\mathrm{y}}\left(\mathrm{N} / \mathrm{mm}^{2}\right)$ & $\mathrm{F}_{\mathrm{u}}\left(\mathrm{N} / \mathrm{mm}^{2}\right)$ \\
\hline $\begin{array}{c}\text { EN 10025-2 } \\
\text { S275 }\end{array}$ & 275 & 430 & 255 & 410 \\
\hline
\end{tabular}

Table 3. Characteristic yield stress and tensile strength of bolt class

Tablo 3. Bulon sinıfinın karakteristik akma gerilmesi ve çekme dayanımı

\begin{tabular}{ccc}
\hline Bolt class & Characteristic yield stress, $\mathrm{F}_{\mathrm{yb}}(\mathrm{MPa})$ & Characteristic tensile strength, $\mathrm{F}_{\mathrm{ub}}(\mathrm{MPa})$ \\
\hline 8.8 & 640 & 800 \\
\hline
\end{tabular}

Table 4. Other design parameters of building models

Tablo 4. Bina modellerinin diğer tasarım parametreleri

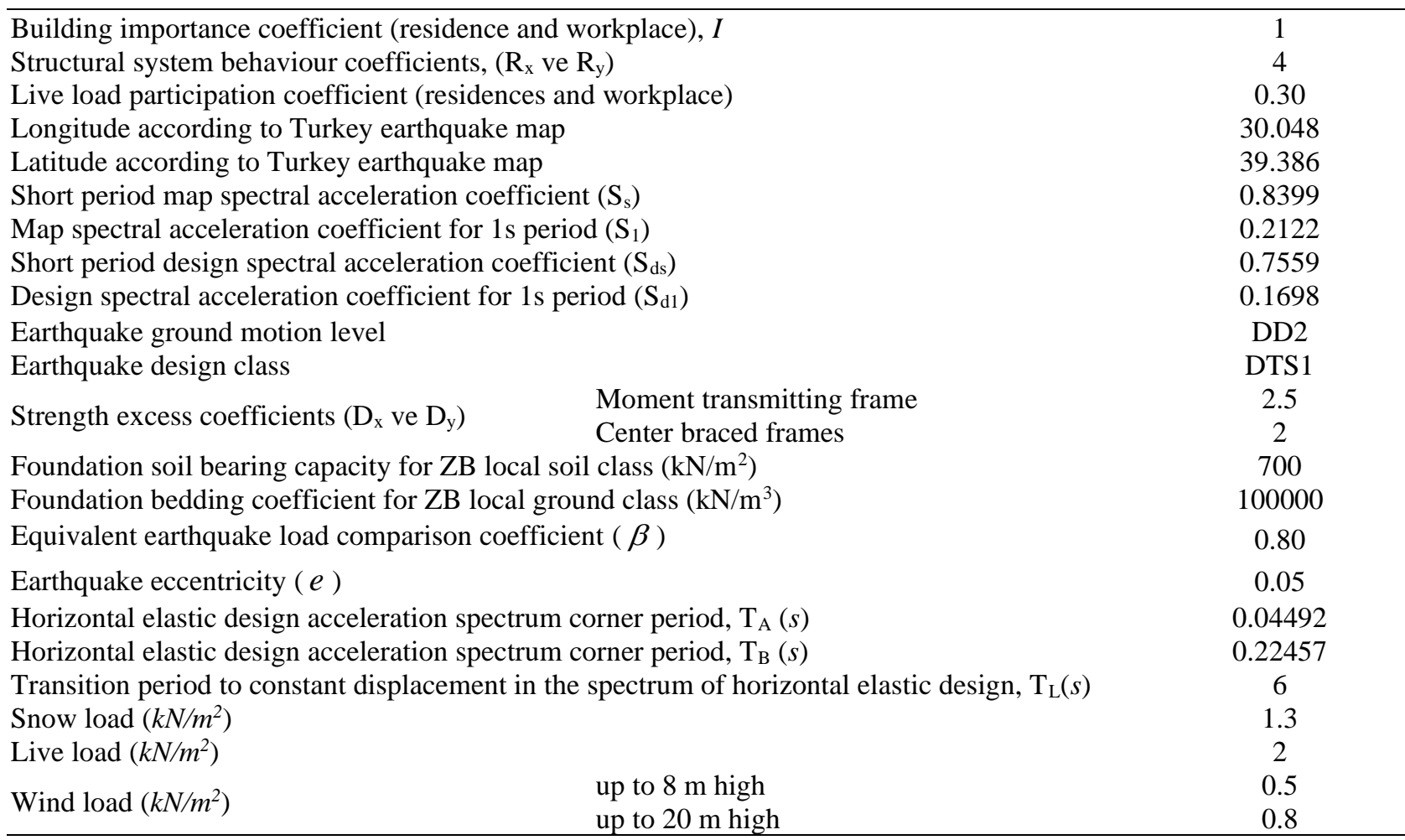

\section{Discussion of findings obtained from structural analyses}

4. Yapısal çözümlemelerden elde edilen bulguların tartışılması

In order to compare the behaviours of the central steel braced building models considered in this article, the critical nodal points and structural elements have been selected as in Figure 5.

The period and angular velocity values obtained from the structural analyses as rigid and semi-rigid of nodal point connections according to the mode superposition method of the considered DLL central steel braced building models are given in Table 5. From this table, it is seen that the period values obtained from model 1 for the first three modes are larger than the central steel braced building models, in spite of that the angular velocity $(\omega)$ values are smaller than the central steel braced building models. On the other hand, in all building models, the period values obtained from the structural analyses carried out with the rigid assumption of the nodal point connections are 
larger than those obtained from the structural analyses carried out with semi-rigid assumption of the nodal point connections. This situation reveals that the period values are significantly reduced in all building models created by using central steel brace members. These findings obtained from structural analyses show that the period values of all building models with increased lateral stiffness by using central steel brace members decrease.

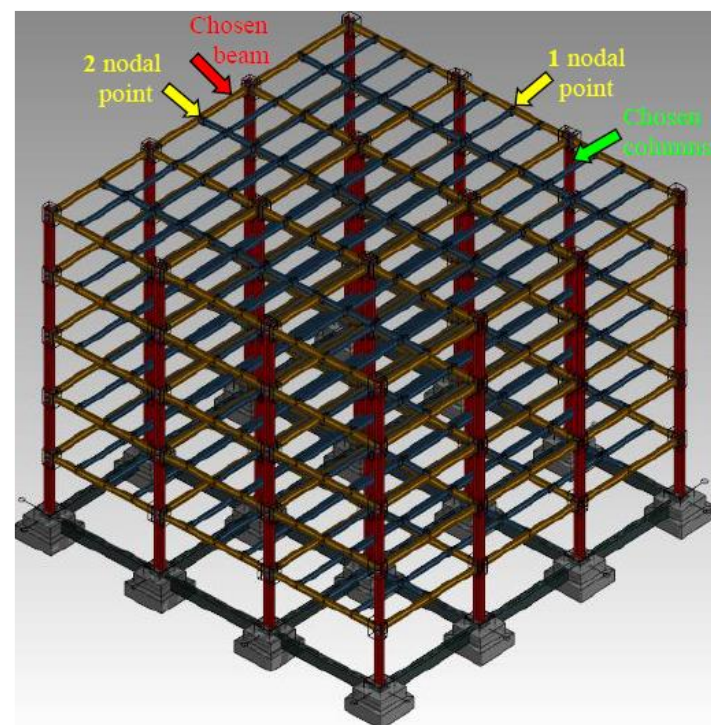

Figure 5. Selected nodal point and structural elements of steel building models

Şekil 5. Çelik bina modellerinin seçilen düğüm noktast ve yapısal elemanlart

Table 5. Period and angular velocity values obtained from rigid and semi-rigid structural analyses of central steel braced building models

Tablo 5. Merkezi çelik çaprazlı bina modellerinin rijit ve yart-rijit yapısal çözümlemelerinden elde edilen periyot ve açısal hız değerleri

\begin{tabular}{lccccccc}
\hline & \multirow{2}{*}{ Models } & \multicolumn{2}{c}{ 1. mod } & \multicolumn{2}{c}{ 2. mod } & \multicolumn{2}{c}{ 3. mod } \\
\cline { 3 - 7 } & & $\mathrm{T}(\mathrm{s})$ & $\omega$ & $\mathrm{T}(\mathrm{s})$ & $\omega$ & $\mathrm{T}(\mathrm{s})$ & $\omega$ \\
\hline \multirow{2}{*}{ Model 1 } & rigid connection & 0.7889 & 7.964 & 0.6708 & 9.367 & 0.5876 & 10.693 \\
& semi-rigid connection & 0.4755 & 13.214 & 0.3929 & 15.992 & 0.3790 & 16.578 \\
Model 2 & rigid connection & 0.5329 & 11.791 & 0.5016 & 12.526 & 0.3132 & 20.061 \\
& semi-rigid connection & 0.4551 & 13.806 & 0.3762 & 16.702 & 0.3207 & 19.592 \\
Model 3 & rigid connection & 0.5440 & 11.550 & 0.5097 & 12.327 & 0.3159 & 19.890 \\
& semi-rigid connection & 0.4581 & 13.716 & 0.3789 & 16.583 & 0.3218 & 19.525 \\
Model 4 & rigid connection & 0.5393 & 11.651 & 0.5035 & 12.479 & 0.3121 & 20.132 \\
& semi-rigid connection & 0.4588 & 13.695 & 0.3783 & 16.609 & 0.3212 & 19.562 \\
Model 5 & rigid connection & 0.5540 & 11.341 & 0.5168 & 12.158 & 0.3228 & 19.465 \\
& semi-rigid connection & 0.4565 & 13.764 & 0.3752 & 16.746 & 0.3269 & 19.221 \\
Model 6 6 6 & rigid connection & 0.5559 & 11.303 & 0.520 & 12.083 & 0.3251 & 19.327 \\
& semi-rigid connection & 0.4639 & 13.544 & 0.3812 & 16.483 & 0.3257 & 19.291 \\
Model 7 & rigid connection & 0.5544 & 11.333 & 0.5197 & 12.090 & 0.3249 & 19.339 \\
& semi-rigid connection & 0.4599 & 13.662 & 0.378 & 16.622 & 0.3259 & 19.280 \\
Model 8 8 & rigid connection & 0.5551 & 1.319 & 0.5185 & 12.118 & 0.3236 & 19.417 \\
& semi-rigid connection & 0.4599 & 13.662 & 0.3779 & 16.627 & 0.3258 & 19.285 \\
\hline & & & & & & &
\end{tabular}

The maximum base shear force values obtained from the structural analyses with the mode superposition and equivalent earthquake load methods for the earthquake effect in the $\mathrm{x}$ and $\mathrm{y}$ directions with the assumptions of rigid and semirigid of nodal point connections with the Sta-Steel program of the building models are given in Table 6 . From this table, it is seen that the base shear force values obtained by assuming rigid the nodal point connections are greater than the base shear force values obtained by assuming the semi-rigid. On the other hand, the base shear force values obtained by the equivalent earthquake load method of the considered building models are greater than those obtained by the mode superposition method in both the $\mathrm{x}$ and $\mathrm{y}$ directions. In addition, the highest base shear force values according to the mode superposition and equivalent earthquake load methods from the structural analyses carried out by assuming rigid the nodal point connections in both the $\mathrm{x}$ and $\mathrm{y}$ directions are obtained from model 2 . But, from the structural analyses performed by assuming that the nodal point connections are semi-rigid, it is seen that the largest base shear 
force values according to the mode superposition method are obtained from model 4 and according to the equivalent earthquake load method are obtained from model 2.

Table 6. Maximum base shear force values obtained from rigid and semi-rigid structural analyses for earthquake effect in $\mathrm{x}$ and $\mathrm{y}$ directions of building models

Tablo 6. Bina modellerinin $x$ ve $y$ doğrultularındaki deprem etkisi için rijit ve yart-rijit yapısal çözümlemelerinden elde edilen maksimum taban kesme kuvveti değerleri

\begin{tabular}{|c|c|c|c|c|c|}
\hline \multirow{3}{*}{ Models } & \multirow{3}{*}{$\begin{array}{l}\text { Connection } \\
\text { type }\end{array}$} & \multicolumn{4}{|c|}{ Maximum base shear force values $(\mathrm{kN})$} \\
\hline & & \multicolumn{2}{|c|}{ Earthquake effect in $\mathrm{x}$ direction } & \multicolumn{2}{|c|}{ Earthquake effect in y direction } \\
\hline & & $\begin{array}{l}\text { mode superposition } \\
\text { method }\end{array}$ & $\begin{array}{c}\text { equivalent earthquake } \\
\text { load method }\end{array}$ & $\begin{array}{l}\text { mode superposition } \\
\text { method }\end{array}$ & $\begin{array}{l}\text { equivalent earthquake } \\
\text { load method }\end{array}$ \\
\hline & rigid & 84.871 & 101.19 & 96.17 & 113.67 \\
\hline model 1 & semi-rigid & 40.272 & 48.934 & 48.321 & 61.398 \\
\hline & rigid & 138.17 & 176.74 & 159.92 & 187.75 \\
\hline model 2 & semi-rigid & 62.459 & 79.935 & 72.606 & 96.699 \\
\hline & rigid & 131.46 & 167.54 & 148.31 & 178.83 \\
\hline model 3 & semi-rigid & 62.489 & 74.885 & 75.681 & 90.544 \\
\hline & rigid & 130.49 & 169.39 & 151.69 & 181.44 \\
\hline moder 4 & semi-rigid & 64.362 & 74.341 & 78.162 & 90.161 \\
\hline model & rigid & 127.73 & 162.86 & 138.62 & 174.57 \\
\hline moder & semi-rigid & 59.059 & 73.508 & 67.727 & 89.448 \\
\hline & rigid & 129.88 & 162.28 & 140.04 & 173.50 \\
\hline moder 0 & semi-rigid & 57.044 & 72.304 & 65.181 & 87.987 \\
\hline model 7 & rigid & 129.76 & 162.38 & 139.09 & 173.23 \\
\hline moder & semi-rigid & 58.579 & 72.939 & 67.261 & 88.736 \\
\hline & rigid & 129.97 & 162.54 & 140.07 & 174.01 \\
\hline model 8 & semi-rigid & 58.277 & 72.898 & 67.004 & 88.714 \\
\hline
\end{tabular}

The values of overturning force, overturning moment, moment against overturning and safety coefficient obtained from structural analyses for earthquake effects in the $\mathrm{x}$ and $\mathrm{y}$ directions with the assumptions of the rigid and semi-rigid of nodal point connections of the building models considered are given in Table 7. From this table, it is seen that the overturning force, overturning moment and anti-overturning moment values obtained by assuming rigid of nodal point connections in the $\mathrm{x}$ and $\mathrm{y}$ directions are larger than those obtained by assuming semi-rigid of nodal point connections. In addition, it is seen that the largest overturning force and overturning moment values by assuming both rigid and semi-rigid in the $\mathrm{x}$ and $\mathrm{y}$ directions are obtained from model 2, by contrast with the anti-overturning moment is obtained from model 3.

The maximum displacement and rotational values at 1 and 2 nodes from the structural analyses carried out with the assumptions of rigid and semi-rigid nodal point connections for the earthquake effect in the $\mathrm{x}$ and $\mathrm{y}$ directions of the DLL central steel braced building models are given in Table 8 . From this table, the displacement values at 1 and 2 nodes obtained from model 1 from the structural analyses performed by assuming the nodal point connections as rigid are larger than the other building models considered. By contrast with, the displacement values at 1 and 2 nodes obtained from model 6 from the structural analyses performed by assuming semi-rigid of nodal point connections are larger than the other building models considered. In addition, the rotation values obtained from model 5 at 1 node for the earthquake effect in the $x$ direction and from the model 6 at 2 nodes for the earthquake effect in the y direction are higher than the other building models. These findings reveal that the building models of the central steel braces significantly affect the displacement and rotational values. 
Table 7. Overturning force, overturning moment, moment against overturning and safety coefficient values according to rigid and semi-rigid structural analyses for earthquake effect in $\mathrm{x}$ and $\mathrm{y}$ directions of building models

Table 7. Bina modellerinin $x$ ve y doğrultularında deprem etkisi için rijit ve yarı-rijit yapısal çözümlemelere göre devrilme kuvveti, devrilme momenti, devrilmeye karşı moment ve güvenlik katsayısı değerleri

\begin{tabular}{|c|c|c|c|c|c|c|c|c|c|c|}
\hline & $\begin{array}{l}\text { Earthquake } \\
\text { direction }\end{array}$ & $\begin{array}{c}\text { Connection } \\
\text { type }\end{array}$ & Model 1 & Model 2 & Model 3 & Model 4 & Model 5 & Model 6 & Model 7 & Model 8 \\
\hline \multirow{8}{*}{  } & \multirow[b]{2}{*}{$\mathrm{X}$} & rigid & 139.98 & 336.27 & 316.91 & 321.7 & 284.79 & 286.79 & 284.95 & 286.42 \\
\hline & & semi-rigid & 60.135 & 152.69 & 142.05 & 145.13 & 130.83 & 130.2 & 131.57 & 129.74 \\
\hline & \multirow[b]{2}{*}{$\mathrm{Y}$} & rigid & 170.5 & 339.04 & 320.36 & 320.39 & 304.72 & 308.32 & 303.2 & 307.3 \\
\hline & & semi-rigid & 71.202 & 163.49 & 145.52 & 146.77 & 145.62 & 145.2 & 144.15 & 143.4 \\
\hline & \multirow{2}{*}{$\mathrm{X}$} & rigid & 1336.6 & 3371.1 & 3181.5 & 3199.4 & 2788 & 2845.9 & 2824.5 & 2835.3 \\
\hline & & semi-rigid & 607.88 & 1531 & 1448.5 & 1449.8 & 1303.4 & 1299.7 & 1309.1 & 1294 \\
\hline & \multirow{2}{*}{ Y } & rigid & 1659.9 & 3362.6 & 3185.2 & 3155.8 & 3023.9 & 3026.5 & 2982.2 & 3023.2 \\
\hline & & semi-rigid & 731.66 & 1640.1 & 1475.7 & 1462.3 & 1451.6 & 1455 & 1442.9 & 1439.5 \\
\hline \multirow{4}{*}{ 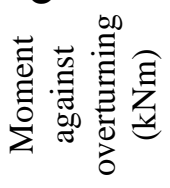 } & \multirow{2}{*}{$\mathrm{X}$} & rigid & 60734 & 62604 & 66113 & 61890 & 61672 & 61676 & 61326 & 61667 \\
\hline & & semi-rigid & 24297 & 25730 & 29452 & 25228 & 25058 & 25058 & 25059 & 25058 \\
\hline & & rigid & 60739 & 62607 & 66122 & 61972 & 61678 & 61678 & 61532 & 61672 \\
\hline & & semi-rigid & 24297 & 25730 & 29453 & 25228 & 25059 & 25058 & 25058 & 25058 \\
\hline \multirow{4}{*}{ 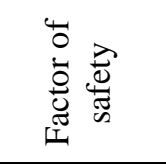 } & \multirow{2}{*}{$\mathrm{X}$} & rigid & 45.44 & 18.571 & 20.78 & 19.344 & 22.12 & 21.671 & 21.712 & 21.75 \\
\hline & & semi-rigid & 39.97 & 16.805 & 20.332 & 17.401 & 19.226 & 19.279 & 19.142 & 19.365 \\
\hline & & rigid & 36.592 & 18.618 & 20.759 & 19.637 & 20.397 & 20.379 & 20.633 & 20.4 \\
\hline & & semi-rigid & 33.208 & 15.688 & 19.959 & 17.253 & 17.262 & 17.223 & 17.367 & 17.408 \\
\hline
\end{tabular}

Table 8. Displacement and rotation values at 1 and 2 nodal points obtained from rigid and semi-rigid structural analyses for earthquake effect in $\mathrm{x}$ and $\mathrm{y}$ directions of models

Tablo 8. Modellerin x ve y doğrultularındaki deprem etkisi için rijit ve yart-rijit yapısal çözümlemelerinden elde edilen 1 ve 2 düğ̈̈m noktalarındaki yerdeğiștirme ve dönme değerleri

\begin{tabular}{|c|c|c|c|c|c|}
\hline \multirow[b]{2}{*}{ Models } & \multirow{2}{*}{$\begin{array}{l}\text { Connection } \\
\text { type }\end{array}$} & \multicolumn{2}{|c|}{$\begin{array}{c}\text { Earthquake effect in the } \mathrm{x} \text { direction } \\
1 \text { nodal point }(18 ; 9 ; 15)\end{array}$} & \multicolumn{2}{|c|}{$\begin{array}{c}\text { Earthquake effect in the y direction } \\
2 \text { nodal point }(9 ; 18 ; 15)\end{array}$} \\
\hline & & $\begin{array}{l}\text { Displacement } \\
\quad \delta_{x}(\mathrm{~cm})\end{array}$ & $\begin{array}{l}\text { Rotation } \\
\theta_{y}(\mathrm{rad})\end{array}$ & $\begin{array}{l}\text { Displacement } \\
\quad \delta_{x}(\mathrm{~cm})\end{array}$ & $\begin{array}{l}\text { Rotation } \\
\theta_{y}(\mathrm{rad})\end{array}$ \\
\hline \multirow{2}{*}{ Model 1} & rigid & 1.164 & 0 & 1.042 & 0 \\
\hline & semi-rigid & 0.792 & 0.00128 & 0.678 & 0.00149 \\
\hline \multirow{2}{*}{ Model 2} & rigid & 0.993 & 0 & 0.950 & 0 \\
\hline & semi-rigid & 0.853 & 0.00233 & 0.772 & -0.00219 \\
\hline \multirow{2}{*}{ Model 3} & rigid & 1.004 & 0 & 0.962 & 0 \\
\hline & semi-rigid & 0.831 & 0.00237 & 0.721 & -0.00204 \\
\hline \multirow{2}{*}{ Model 4} & rigid & 1.004 & 0 & 0.945 & 0 \\
\hline & semi-rigid & 0.830 & 0.00226 & 0.718 & -0.00195 \\
\hline \multirow{2}{*}{ Model 5} & rigid & 1.015 & 0 & 0.984 & 0 \\
\hline & semi-rigid & 0.844 & 0.00254 & 0.771 & -0.00233 \\
\hline \multirow{2}{*}{ Model 6} & rigid & 1.01 & 0 & 0.987 & 0 \\
\hline & semi-rigid & 0.857 & 0.00252 & 0.787 & -0.00236 \\
\hline \multirow{2}{*}{ Model 7} & rigid & 1.003 & 0 & 0.983 & 0 \\
\hline & semi-rigid & 0.844 & 0.0025 & 0.769 & -0.00231 \\
\hline \multirow{2}{*}{ Model 8} & rigid & 1.004 & 0 & 0.981 & 0 \\
\hline & semi-rigid & 0.845 & 0.00251 & 0.773 & -0.00232 \\
\hline
\end{tabular}

The maximum deflection and displacement values of the beam selected from the structural analyses performed with rigid and semi-rigid assumptions of the nodal point connections of the building models are given in Table 9. 
Table 9. The maximum deflection and displacement values of the selected beam from the structural analyses with the rigid and semi-rigid acceptance of the nodal point combination of the building models

Tablo 9. Bina modellerinin düğ̈̈m noktası birleşimlerinin rijit ve yart-rijit kabulüyle yapısal çözümlemelerinden seçilen kirişinin maksimum sehim ve yerdeğiştirme değerleri

\begin{tabular}{|c|c|c|c|c|c|}
\hline Models & $\begin{array}{c}\text { Connection } \\
\text { type }\end{array}$ & Beam length $L(\mathrm{~mm})$ & $\begin{array}{l}\text { Maximum deflection } \\
(\mathrm{mm})\end{array}$ & $\begin{array}{l}\text { Maximum displacement } \\
(\mathrm{mm})\end{array}$ & Limit deflection $(L / 300)$ \\
\hline \multirow[t]{2}{*}{ Model 1} & rigid & 6000 & 1.1577 & 1.8958 & 20 \\
\hline & semi-rigid & 5562 & 0.34035 & 0.47405 & 18.54 \\
\hline \multirow[t]{2}{*}{ Model 2} & rigid & 6000 & 1.1495 & 1.8466 & 20 \\
\hline & semi-rigid & 5562 & 0.31634 & 0.45269 & 18.54 \\
\hline \multirow[t]{2}{*}{ Model 3} & rigid & 6000 & 1.0738 & 1.7802 & 20 \\
\hline & semi-rigid & 5562 & 0.3076 & 0.4499 & 18.54 \\
\hline \multirow[t]{2}{*}{ Model 4} & rigid & 6000 & 1.2324 & 1.8736 & 20 \\
\hline & semi-rigid & 5562 & 0.41366 & 0.56269 & 18.54 \\
\hline \multirow[t]{2}{*}{ Model 5} & rigid & 6000 & 1.1574 & 1.8873 & 20 \\
\hline & semi-rigid & 5562 & 0.34557 & 0.48007 & 18.54 \\
\hline \multirow[t]{2}{*}{ Model 6} & rigid & 6000 & 1.1035 & 1.7994 & 20 \\
\hline & semi-rigid & 5562 & 0.31537 & 0.45034 & 18.54 \\
\hline \multirow[t]{2}{*}{ Model 7} & rigid & 6000 & 1.1022 & 1.8216 & 20 \\
\hline & semi-rigid & 5562 & 0.33417 & 0.47037 & 18.54 \\
\hline \multirow[t]{2}{*}{ Model 8} & rigid & 6000 & 1.1365 & 1.8535 & 20 \\
\hline & semi-rigid & 5562 & 0.33141 & 0.46712 & 18.54 \\
\hline
\end{tabular}

From this table, it is seen that the maximum deflection and displacement values obtained by assuming the nodal point connections as rigid are greater than those obtained by assuming the semirigid nodal point connection. In addition, the largest deflection values with both rigid and semirigid assumptions are obtained from model 4 , by contrast with the displacement values are obtained from model 1 with the assumption of rigid and model 4 with the assumption of semi-rigid.

The displacement distributions at the storey levels along the building height from the structural analyses with assumptions of the rigid and semirigid of the nodal point connections for earthquake effect in the $\mathrm{x}$ and $\mathrm{y}$ directions of the building models are given in Figure 6-9, respectively. From these figures, it is seen that the displacement distributions at the storey levels of the building models having central steel brace members are smaller than the displacement distributions obtained from model 1 . In addition, the displacement distributions obtained by assuming that the nodal point connections are rigid are larger than the displacement distributions obtained by assuming that the nodal point connections are semi-rigid. These findings prove that the displacement distribution values obtained by assuming that the nodal point connections of the building models with different central steel braces are both rigid and semi-rigid have decreased significantly compared to model 1 that the reference model. In other words, this situation reveals that these building models perform better than the reference model.

The variation of the earthquake load with the central steel brace ratio, from the structural analyses performed with rigid and semi-rigid assumptions of the nodal point connections of the building models is given in Figure 10. From this figure, it is seen that the earthquake load increases with the increase of the central steel brace ratio. In addition, the earthquake load values obtained by assuming that the nodal point connections are rigid are greater than the earthquake load values obtained by assuming that the nodal point connections are semi-rigid. This finding reveals how important the nodal point connections are in steel structures and that they significantly affect the earthquake load values. 


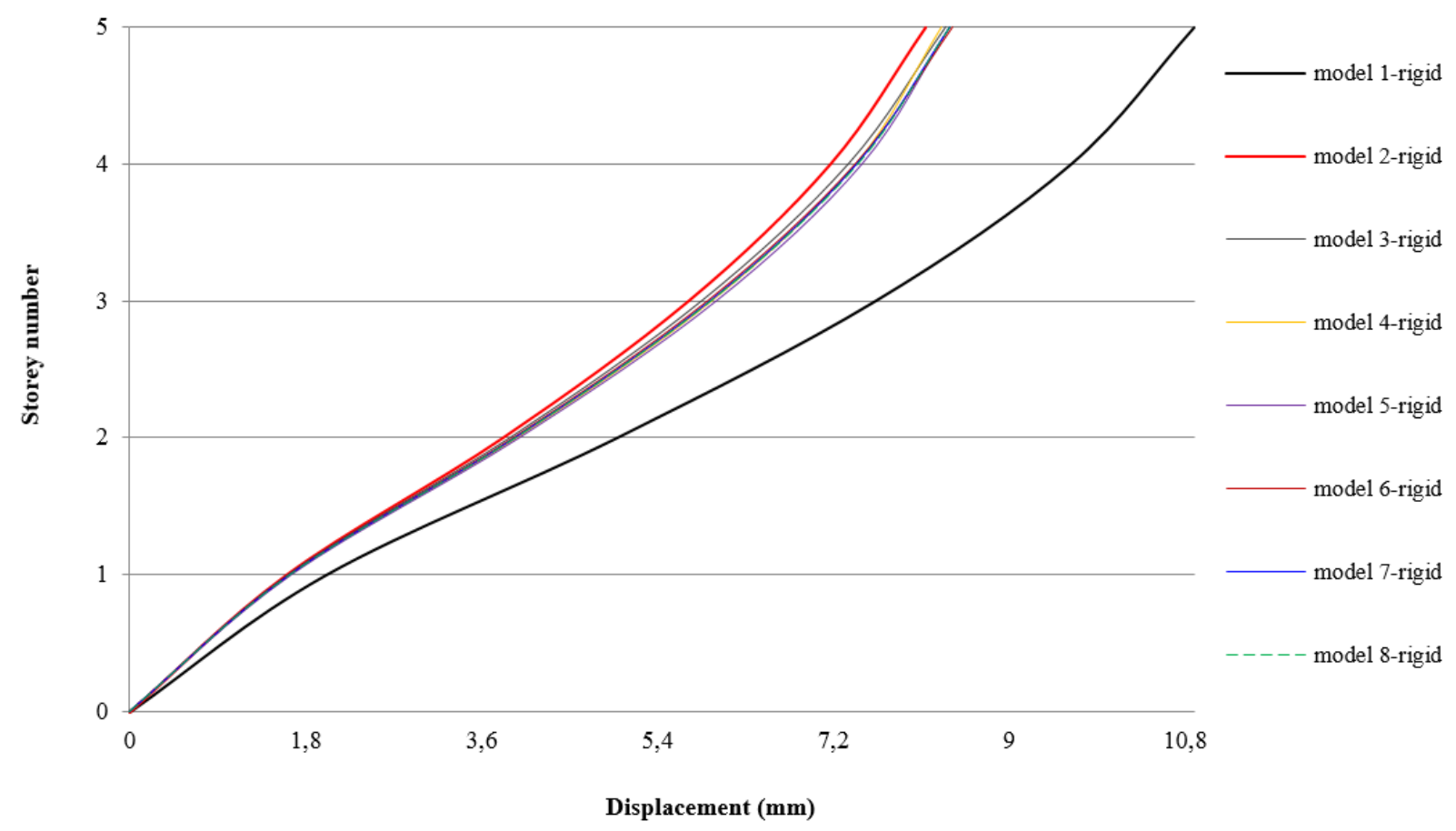

Figure 6. The displacement values at the storey levels of the column selected for the $\mathrm{x}$-direction earthquake effect, assuming that the nodal point combination of the building models is rigid

Şekil 6. Bina modellerinin düğ̈̈m noktası birleşimlerinin rijit olduğu kabulüyle x doğrultusundaki deprem etkisi için seçilen kolonunun kat seviyelerindeki yerdeğiş̧tirme değerleri

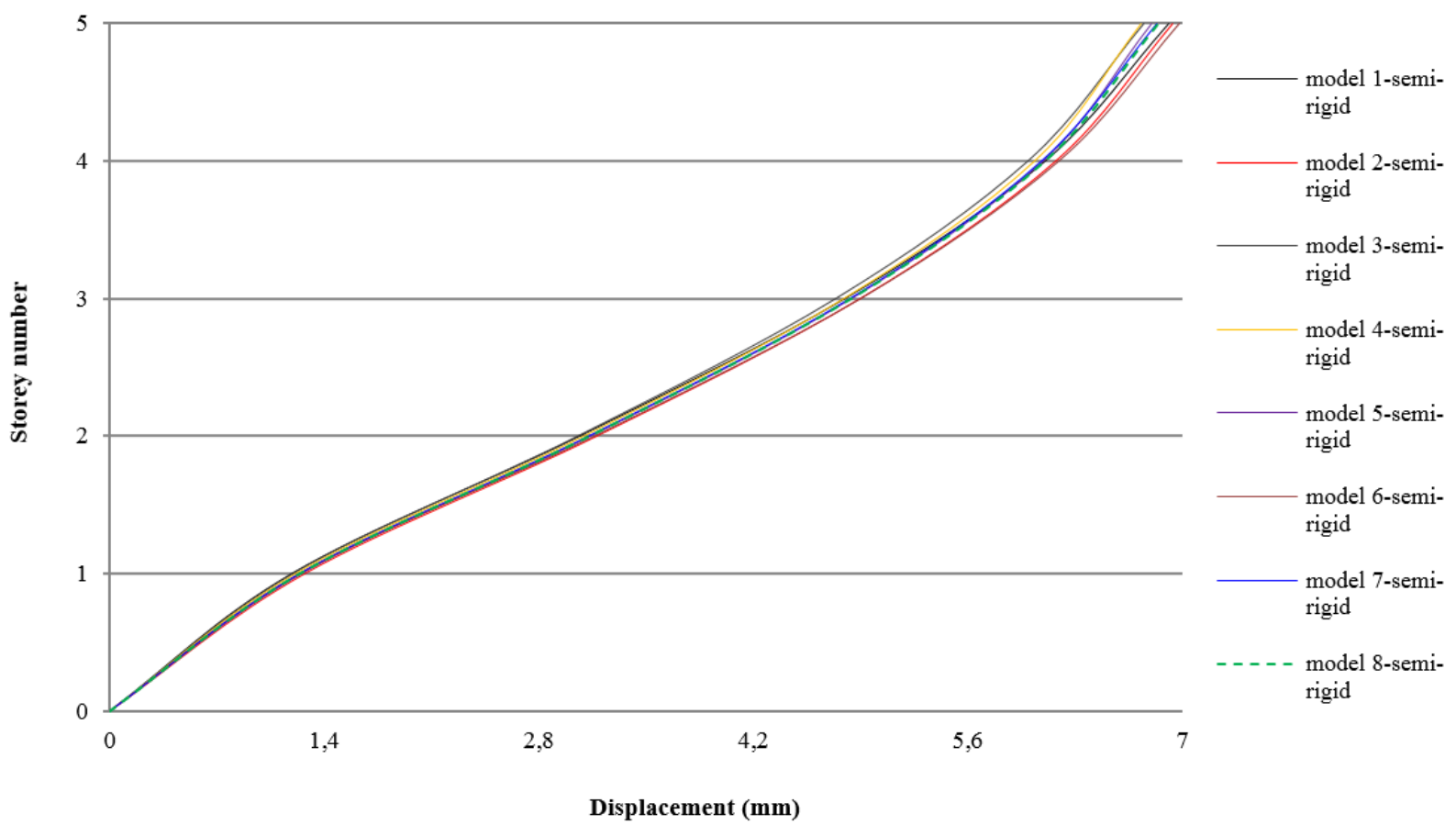

Figure 7. The displacement values at the storey levels of the column selected for the $\mathrm{x}$-direction earthquake effect, assuming that the nodal point combination of the building models is semi-rigid Şekil 7. Bina modellerinin dügüm noktası birleşimlerinin yart-rijit olduğu kabulüyle x doğrultusundaki deprem etkisi için seçilen kolonunun kat seviyelerindeki yerdeğiştirme değerleri 


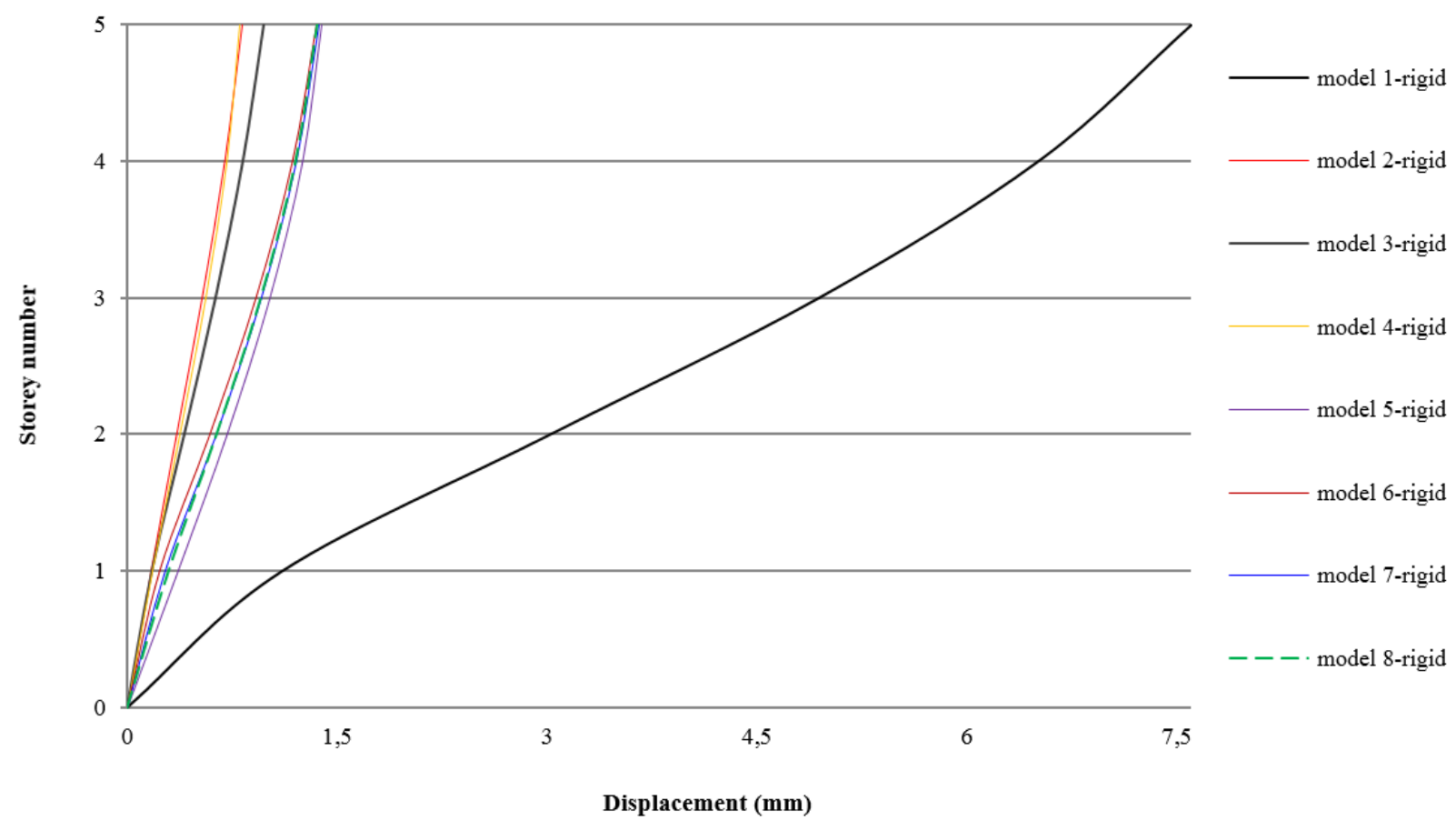

Figure 8. The displacement values at the storey levels of the column selected for the y-direction earthquake effect, assuming that the nodal point combination of the building models is rigid

Şekil 8. Bina modellerinin düğ̈̈m noktası birleşimlerinin rijit olduğu kabulüyle y doğrultusundaki deprem etkisi için seçilen kolonunun kat seviyelerindeki yerdeğiş̧tirme değerleri

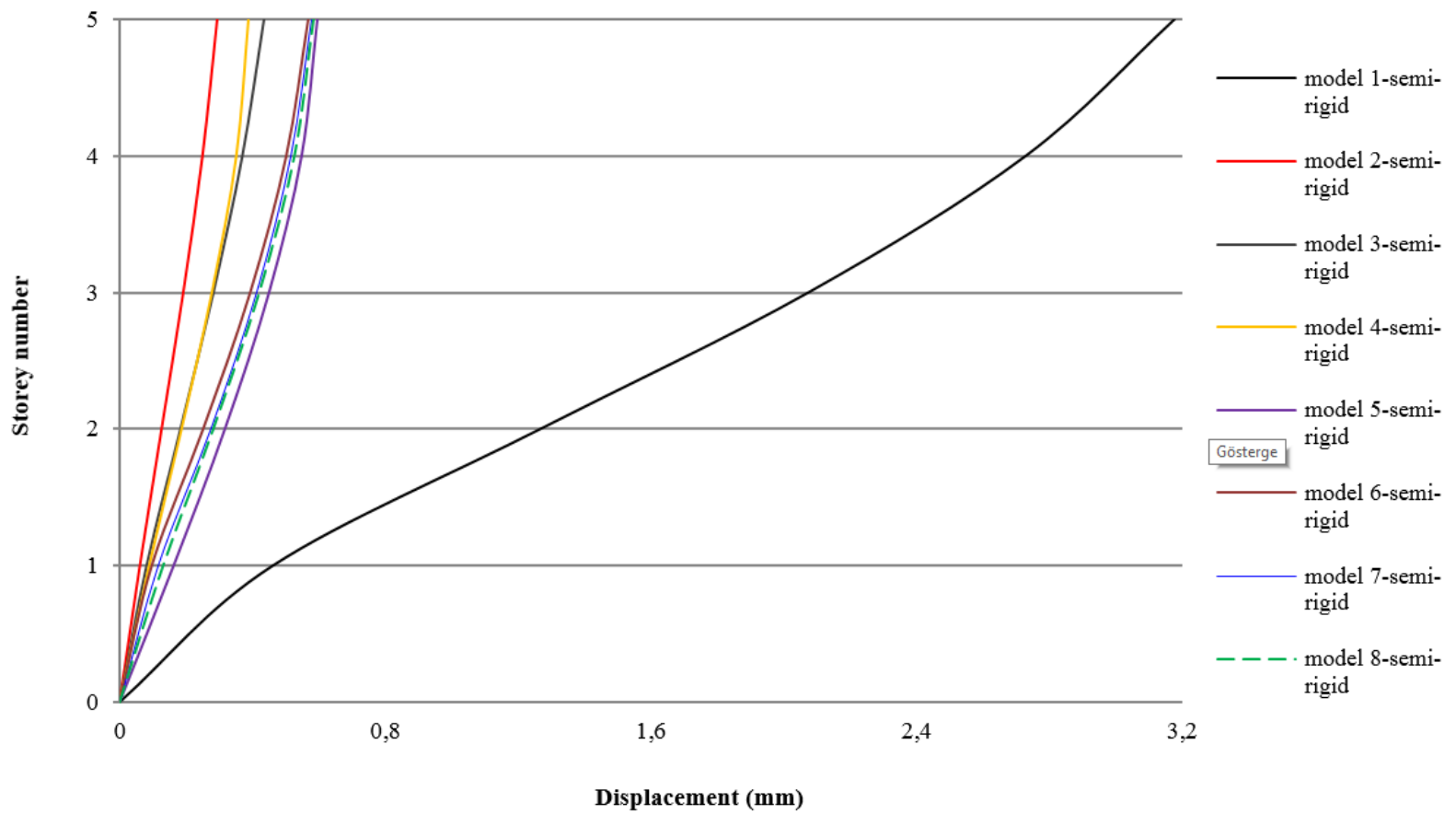

Figure 9. The displacement values at the storey levels of the column selected for the y-direction earthquake effect, assuming that the nodal point combination of the steel building is semi-rigid

Şekil 9. Bina modellerinin düğüm noktası birleşimlerinin yarı-rijit olduğu kabulüyle y doğrultusundaki deprem etkisi için seçilen kolonunun kat seviyelerindeki yerdeğiştirme değerleri 


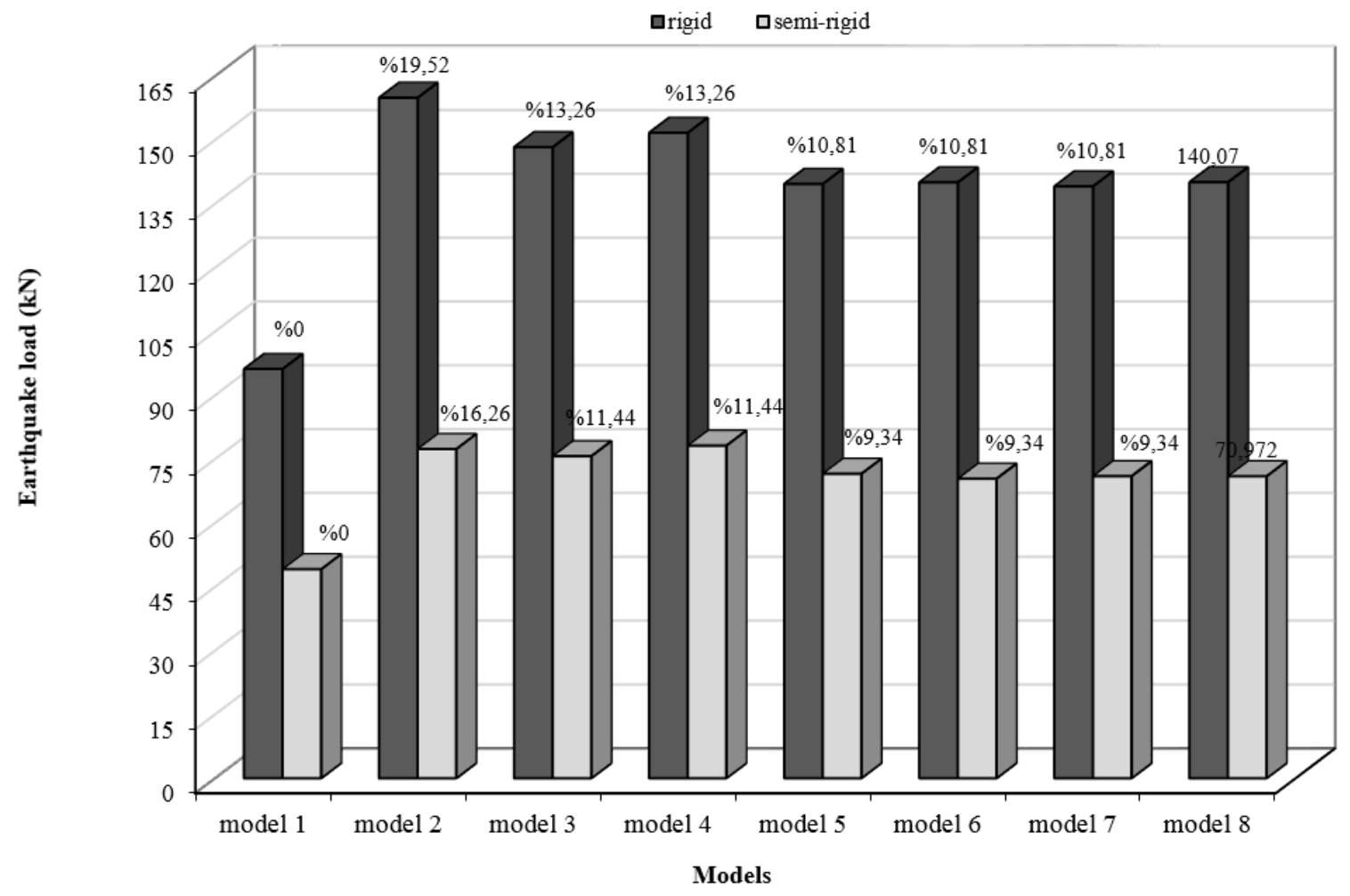

Figure 10. Earthquake load values of building models according to different central steel cross ratios, assuming that the nodal point combination is rigid and semi-rigid

Şekil 10. Dügüm noktası birleşimlerinin rijit ve yart-rijit olduğu kabulleriyle farklı merkezi çelik çapraz oranlarına göre bina modellerinin deprem yükü değerleri

\section{Conclusions and recommendations 5. Sonuçlar ve Öneriler}

The main conclusions and recommendations from this study are summarized below.

- From the structural analyses, the period values obtained from model 1 for the first three modes are greater than the models with central steel braces. By contrast with, angular velocity values are obtained smaller than the central steel braced models. This result reveals that the central brace members, which increase the lateral stiffness of the models, decrease the period of the structure in question, thus making a positive contribution to the behaviour of the structure.

- In all building models, the period values obtained by assuming that rigid of nodal points are larger than those obtained by assuming that the nodal points are semi-rigid. This result reveals that nodal point details are very important in the design of steel structures.

- The base shear force values obtained by the equivalent earthquake load method in both the $\mathrm{x}$ and $\mathrm{y}$ directions of the building models are greater than those obtained by the mode superposition method. Assuming that the nodal point connections of the building models are rigid, the maximum base shear force value obtained from model 2 by mode superposition and the equivalent earthquake load methods in the $\mathrm{x}$-direction is $62.8 \%$ and $74.66 \%$ greater than model 1 , respectively. In addition, the maximum base shear force value obtained from model 2 by mode superposition and the equivalent earthquake load methods in the $y$ direction is calculated larger $66.29 \%$ and $65.17 \%$ according to model 1 , respectively. Assuming that the nodal points are semi-rigid, the maximum base shear force value obtained from model 4 by mode superposition method in $\mathrm{x}$ and $\mathrm{y}$ directions is $59.82 \%$ and $61.76 \%$ compared to model 1 , respectively, and the maximum base shear force value obtained from model 2 by equivalent earthquake load method is $63.35 \%$ and $57.49 \%$ greater compared to model 1 , respectively.

- As a result of the structural analyses, the base shear force values obtained by assuming that rigid of nodal points are greater than the base shear force values obtained by assuming that the nodal points are semi-rigid. This result reveals 
that rigid nodal points will meet greater base shear force and transferring the moment.

- Findings obtained from the structural analyses; it is reveals that the building model with twoway central steel brace members behaves better than the taken into account other building models. This result shows that two-way central steel brace members significantly increase the performance of the structure.

- The overturning force, overturning moment and anti-overturning moment values obtained by assuming the nodal points as rigid are larger than those obtained by assuming the semi-rigid nodal points.

- Displacement distributions at storey levels in both $\mathrm{x}$ and $\mathrm{y}$ directions of different central steel braced building models are smaller than those of the moment-transmitting building model. This result reveals that different central steel brace members that increase the lateral stiffness of the structure increase the performance of the structure in question.

- The displacement distributions obtained at the story levels from the structural analyses performed by assuming that the nodal point connections are rigid in both the $\mathrm{x}$ and $\mathrm{y}$ directions are greater than the displacement distributions obtained by assuming that the nodal point connections are semi-rigid.

- As a result of the structural analyses carried out with the assumption that the nodal points are both rigid and semi-rigid, the earthquake load values increase with the increase in the central steel brace ratio. In addition, the earthquake load values obtained by assuming that the nodal points are rigid are greater than the earthquake load values obtained by assuming that the nodal points are semi-rigid. This result shows that nodal point connections affect earthquake load values, too.

- The largest displacement value of the selected nodal points (for 1 and 2 nodal points) from the structural analyses which is performed by assuming rigid of the nodal point connections of the building models is obtained from model 1 . By contrast with, the largest displacement value from the structural analyses performed with the assumption of semi-rigid is obtained from model 6. This result shows that the central steel brace types significantly reduce the displacement values of the considered models compared to the moment-transferring frame, except for model 6 in the semi-rigid joint.

- It is recommended to use two-way (X) central steel brace members in the design and construction of steel structures that will be built in Turkey when the findings of this study are examined.

\section{Acknowledgments \\ Teşekkür / Katkı belirtme}

The license of the Sta-Steel program used in this study was obtained by the Rectorate of Karabük University.

\section{Author contribution \\ Yazar katkısı}

This article is a part of Büşra CENGIZ's master's thesis the supervision of Prof. Dr. Şenol GÜRSOY

\section{Declaration of ethical code \\ Etik beyanı}

Authors of this article declare that materials and methods used in this study do not require ethical committee approval and/or legal-specific permission.

\section{Conflict of interest}

Çıkar çatışması beyanı

Authors declare that there is no conflict of interest.

\section{Kaynaklar \\ References}

Ay, Z., Çelik, İ.D. \& Kımıllı, N. A. (2010). Some assessments on seismic performance of braced steel frames. Erciyes Üniversitesi Fen Bilimleri Enstitüsü Dergisi, 26(1), 7-17. (in Turkish)

Cengiz, B. (2020). An investigation of the effects of central steel bracing types on the joint connection detail and frame behavior. MSc. Thesis, Karabük University Graduate Education Institute, Karabük. (in Turkish)

Çavdar, Ö. (2017). Investigation of dynamic behavior of steel structures with different brace member, Uluslararası Katılımlı 7. Çelik Yapılar Sетроzуити, Gaziantep, 193-203.

Çavdar, Ö. (2019). Determination of the Seismic Performance of Concentrically Braced Steel Structures, International Journal of Science and Engineering Applications, 8(12), 503-508. https://dx.doi.org/10.7753/IJSEA0812.1002 
ÇYTHYDE. (2018). Regulation on the Design, Calculation and Construction Principles of Steel Structures. Environment and Urban Ministry. Turkey. (in Turkish)

Gönen, H. (1997). Controls of lateral displacements of multi-storey steel frames by diagonal elements. Osmangazi Üniversitesi Müh. Mim. Fak. Dergisi, 10(1), 59-70. (in Turkish)

Kural, M. E. \& Zeybek, Ö. (2011). Second order analysis of multi storey steel structures that are formed by concentric steel braces. Istanbul Commerce University Journal of Science, 10(20), 1-14. (in Turkish)

Özçelik, R. (2016). Buckling restrained braces. Pamukkale University Journal of Engineering Sciences, 22(3), 160-170.

Sta-Steel, (2019). Structural analysis for steel structure. ver.1.3.0.3.

https://www.sta4.net/steeldefault.aspx

Tama, Y. S. (2003). The moment resisting frames on steel structures. Pamukkale University Journal of Engineering Sciences, 9(1), 63-72. (in Turkish)
TBEC. (2019). Turkey Building Earthquake Code. Disaster and Emergency Management Presidency, Ankara, Turkey. (in Turkish)

TS-498. (1997). Calculation Values of Loads to be Taken in the Dimensioning of Structural Elements. Turkish Standards Institute, Ankara, Turkey. (in Turkish)

TS EN 1991-1-3 (2007). Yapılar Üzerindeki EtkilerBölüm 1-3: Genel Etkiler-Kar Yükleri (Eurocode 1), Türk Standartları Enstitüsü, Ankara

Türk, B. (2016). Evaluation the seismic performance of a special concentrically braced frame. MSc. Thesis, İstanbul Technical University Graduate School of Natural and Applied Sciences, İstanbul. (in Turkish)

Yelgin, N. A. \& Bulut, B. M. (2016). Merkezi çaprazlı ve dışmerkez çaprazlı çok katlı binaların Eurocode EC1, EC3, EC4 ve EC8 yönetmeliklerine göre dizayn kuralları ve süneklilik düzeylerinin karşılaştırılması, 4th International Symposium on Innovative Technologies in Engineering and Science, Antalya, 142-149. 